\title{
STUDENTS' PERCEPTION OF LEARNING MANAGEMENT SYSTEM (LMS) UTILIZED IN ONLINE ENGLISH LEARNING SITUATION DURING COVID-19 PANDEMIC
}

\author{
Denita Azzahra Ramadania \\ University of Muhammadiyah Prof. Dr. HAMKA \\ denitaswork@gmail.com
}

\begin{abstract}
This research is aimed to figure out the students' perceptions of Learning Management Systems (LMS) that they utilized in Online English Learning Situation during Covid-19 Pandemic. Nowadays, many teachers have changed their face-to-face learning to full online learning as the impact of coronavirus outbreak. This situation creates new model of learning in which Learning Managements System or LMS becomes one of platform that are used by both teachers and students to support learning. The various LMS such as Google Classroom, Edmodo, Schoology, Moodle, and etc. are gained interest and popular in education context including English Language Learning (ELL) and Teaching (ELT). Hence, the writer tries to expose the valuable insight from the students' perception towards those LMS by conducting a quantitative study within survey design and instruments. This research involved 125 respondents mainly from Jabodetabek area. After the data has been collected, the writer analyzed it by using Ms. Excel 2010. The result showed a positive sight from the students. They seemed enjoy using LMS, since it facilitates students in learning English with easy features to submit assignment, quiz, feedback, and communication forum.
\end{abstract}

Keywords: EFL students' perception, learning management system, online learning

\section{INTRODUCTION}

These days technology expands rapidly and interfere every pillar or aspects of human's life including education matter. Its development is unstoppable which make education stakeholders have to adapt and applied technology in teaching and learning process. As well as teacher cannot refuse the fact that today's teaching must run technology-supported learning (Bhalla, 2013). It is supported by Shatunova et al (2019) who claimed that the pace of technology expansion has changed education system.. The expansion of educational technology is also massively utilized in context of English Language Teaching or Learning (ELT or ELL). This goes along with Istifci (2017) who stated that language learning including English has been affected by technological development. For instance, English teachers nowadays are familiar in implementing audio-visual aids such as print texts and film in classroom which supports students to be more familiar with vocabulary and language structures (Ahmadi, 2018) or students use audio digital mp3 such as podcast to improve their listening skill, since they found its easier, faster, and attractive for their learning (Alfa, 2020). Teachers can teach English for students more sophisticated than conventional tools, and students can learn any skill of English, and they can access any topic of language on a platform by themselves. Therefore, the differences in the learning method used today are evidence of technological improvement. 
Recently, one of English Language Teaching technology development is led by the creation of Learning Management System or usually called by LMS. Learning Management System (LMS) is a software application which integrating technological and pedagogical features into a well-developed virtual learning environment (Cavus, 2011). The high demands of LMS application is reasonably appeared due to the COVID-19 pandemic which is happening in all over the world including Indonesia. As we know, teachers and students should stay at home due to the government's regulation which enforces schools or campuses' activity restriction in aim to stop the spread of COVID 19 Pandemic. This regulation is about moving school or campus activities to home (https://setkab.go.id). It means the conventional learning method or face to face learning is switched to full online learning activities.

The online learning activity on Learning Management System (LMS) brings out different experiences and perception for students and teachers. It drives students to develop their target language skills and active their independent learning Ling et al., (2019), since everything that they need such as course material, exercise, and feedback are serve in the Learning Management System Platform. However, there are also contrary side in line with distance education through this LMS utilization such as it may marginalize students (Deli \& Allo, 2020). They will suffer by themselves and lose motivation, since what they see is only their screen. Besides, the Learning Management System (LMS) is required by internet connection which is not always in a stable condition; thus, students often need to struggle with this problem. Moreover, the lack of equity in access to uninterrupted internet proving to be a hassle to many students (Muthuprasad et al, 2021).

The sounds of LMS negativity above are reasonable since the utilization of this platform is quite new especially in Indonesia. Therefore, the writer is interested to study research entitled “students' perception of Learning Management System (LMS) Utilized in Online English Learning Situation during Covid-19 Pandemic". In this context of research, the writer is intrigued to examine the students' perception of using Learning Management System in English learning that will be focused more on Senior High School and Junior High School students' response.

\section{METHOD}

To conduct this study, a quantitative approach with survey method of Closed-ended and Openended questionnaire was used. This approach is appropriate to this study, since according to Leavy (2017) the main advantage is you could collect an extensive range of data from a large number of respondents, which would allow the writer to make determinations about EFL students' perception of Learning Management System (LMS) utilized to facilitate their online English learning.

Closed-ended and open-ended questionnaire developed by Pérez-pérez et al. (2019), Damnjanovic et al. (2015), and Komara, (2020) is five point Likert's scale contain of 20 items, while one item of open-ended questionnaire was used to determine students; perception more deeply. The questionnaire used online Google Form as a tool to collect data. It was distributed 
through WhatsApp chat application to 125 Junior and Senior High School students in Jabodetabek region. The data was analyzed statistically with Cronbach Alpha Statistic to find the reliability and descriptive statistics to indicate the mean and standard deviation to make an appropriate calculation through the data obtained with students' response.

\section{FINDINGS AND DISCUSSION}

In this chapter, the writer presented the findings of data gathered from two instruments which were close-ended questionnaire and open-ended questionnaire. It was discovered an evidence of students' perception of using Learning Management System (LMS) such as Google Classroom, Schoology, Edmodo, Moodle, etc. to accommodate their English learning during the COVID 19 Pandemic.

\section{Closed-Ended Questionnaire}

In order to get student's perception of Learning Management System, the close-ended questionnaire which contain of 20 statements were asked to 125 participants in Senior and Junior High School in Jabodetabek region. To be informed first, the writer performed a reliability test on a closed-ended questionnaire item using the Cronbach' Alpha Statistic as the instrument' requirement. Below was the result:

Table 1: Reliability Statistic

\begin{tabular}{cc}
\hline Cronbach's Alpha & N of Items \\
\hline $\mathbf{9 5 0}$ & $\mathbf{2 0}$ \\
\hline
\end{tabular}

Based on the table above, the writer got count for reliability of Cronbach's Alpha score, it was 0.950. According to (Vaske \& Beaman, 2008) 0.950 is categorized as high score. Therefore, it can be said that variable is reliable and item responses positively correlated to with each other. Next is the tabulation of closed-ended questionnaires which has five point answers to determine students' perception which Strongly Agree (SA), Agree (A), Neutral (N), Disagree (D), and Strongly Disagree (SD). Here is the tabulation.

Table 2: Participants' Answer for Closed-Ended Questionnaire

\begin{tabular}{|c|c|c|c|c|c|c|c|}
\hline No & Statements & $\mathbf{X}$ & $\mathbf{S A}$ & $\mathbf{A}$ & $\mathbf{N}$ & D & SD \\
\hline 1. & $\begin{array}{l}\text { LMS platform I use is } \\
\text { good and interesting. }\end{array}$ & 3.92 & $\begin{array}{c}31 \\
(24.8 \%)\end{array}$ & $\begin{array}{c}59 \\
(47.2 \%)\end{array}$ & $\begin{array}{c}29 \\
(23.2 \%)\end{array}$ & $\begin{array}{c}6 \\
(4.8 \%)\end{array}$ & $\begin{array}{c}0 \\
(0 \%)\end{array}$ \\
\hline 2. & $\begin{array}{l}\text { I have got a new } \\
\text { experience } \\
\text { learning English using } \\
\text { LMS } \\
\text { Platform. }\end{array}$ & 3.97 & $\begin{array}{c}41 \\
(32.8 \%)\end{array}$ & $\begin{array}{c}46 \\
(36.8 \%)\end{array}$ & $\begin{array}{c}32 \\
(25.6 \%)\end{array}$ & $\begin{array}{c}6 \\
(4.8 \%)\end{array}$ & $\begin{array}{c}0 \\
(0 \%)\end{array}$ \\
\hline 3. & $\begin{array}{l}\text { I find quite easy to learn } \\
\text { English with the LMS } \\
\text { platform I use. }\end{array}$ & 3.8 & $\begin{array}{c}30 \\
(24 \%)\end{array}$ & $\begin{array}{c}52 \\
(41.6 \%)\end{array}$ & $\begin{array}{c}32 \\
(25.6 \%)\end{array}$ & $\begin{array}{c}10 \\
(8 \%)\end{array}$ & $\begin{array}{c}1 \\
(0.8 \%)\end{array}$ \\
\hline
\end{tabular}




\begin{tabular}{|c|c|c|c|c|c|c|c|}
\hline 4. & $\begin{array}{l}\text { I like learning English } \\
\text { with the LMS Platform I } \\
\text { use. }\end{array}$ & 3.89 & $\begin{array}{r}35 \\
(28 \%)\end{array}$ & $\begin{array}{c}48 \\
(38.4 \%)\end{array}$ & $\begin{array}{c}36 \\
(28.8 \%)\end{array}$ & $\begin{array}{c}6 \\
(4.8 \%)\end{array}$ & $\begin{array}{c}0 \\
(0 \%)\end{array}$ \\
\hline 5. & $\begin{array}{l}\text { Using LMS Platform is } \\
\text { more fun for me. }\end{array}$ & 3.72 & $\begin{array}{c}29 \\
(23.2 \%)\end{array}$ & $\begin{array}{c}44 \\
(35.5 \%)\end{array}$ & $\begin{array}{c}41 \\
(32.8 \%)\end{array}$ & $\begin{array}{c}11 \\
(8.8 \%)\end{array}$ & $\begin{array}{c}0 \\
(0 \%)\end{array}$ \\
\hline 6. & $\begin{array}{l}\text { I feel motivated to learn } \\
\text { English using LMS } \\
\text { Platform. }\end{array}$ & 3.60 & $\begin{array}{c}19 \\
(15.2 \%)\end{array}$ & $\begin{array}{c}52 \\
(41.6 \%)\end{array}$ & $\begin{array}{c}43 \\
(34.3 \%)\end{array}$ & $\begin{array}{c}8 \\
(6.4 \%)\end{array}$ & $\begin{array}{r}3 \\
(2.4 \%)\end{array}$ \\
\hline 7. & $\begin{array}{l}\text { I feel actively learning } \\
\text { English using LMS } \\
\text { Platform. }\end{array}$ & 3.48 & $\begin{array}{r}20 \\
(16 \%)\end{array}$ & $\begin{array}{c}39 \\
(31.2 \%)\end{array}$ & $\begin{array}{r}50 \\
(40 \%)\end{array}$ & $\begin{array}{c}13 \\
(10.4 \%)\end{array}$ & $\begin{array}{c}3 \\
(2.4 \%)\end{array}$ \\
\hline 8. & $\begin{array}{l}\text { I find quite easy to } \\
\text { understand English } \\
\text { material presented in the } \\
\text { LMS. }\end{array}$ & 3.4 & $\begin{array}{r}20 \\
(16 \%)\end{array}$ & $\begin{array}{c}31 \\
(24.8 \%)\end{array}$ & $\begin{array}{r}55 \\
(44 \%)\end{array}$ & $\begin{array}{c}17 \\
(13.6 \%)\end{array}$ & $\begin{array}{c}2 \\
(1.6 \%)\end{array}$ \\
\hline 9. & $\begin{array}{l}\text { I feel my English skills } \\
\text { improved after learning } \\
\text { using } \\
\text { LMS platform. }\end{array}$ & 3.70 & $\begin{array}{c}26 \\
(20.8 \%)\end{array}$ & $\begin{array}{c}51 \\
(40.8 \%)\end{array}$ & $\begin{array}{r}35 \\
(28 \%)\end{array}$ & $\begin{array}{r}11 \\
(8.8 \%)\end{array}$ & $\begin{array}{c}2 \\
(1.6 \%)\end{array}$ \\
\hline
\end{tabular}

10. My English scores after learning with LMS Platform are still good and they are even $\begin{array}{rrrrrr} & 15 & 36 & 59 & 14 & 1 \\ & (12 \%) & (28.8 \%) & (47.2 \%) & (11.2 \%) & (0.8)\end{array}$ improving.

11. Features in the LMS platform I use are quite easy in facilitating my English learning.

$\begin{array}{cccccr}3.75 & 28 & 46 & 43 & 8 & 0 \\ & (22.4 \%) & (36.8 \%) & (34.4 \%) & (6.4 \%) & (0 \%)\end{array}$

12. LMS platform I use provides adequate communication space and interactive discussions between

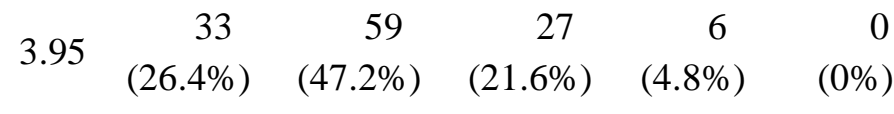
friends and teachers.

13. $\begin{aligned} & \text { Features in the LMS } \\ & \text { Platform (materials, } \\ & \text { assignments, quizzes, } \\ & \text { forums / chat, audio, } \\ & \text { video, live chat) are } \\ & \text { complete and adequate. }\end{aligned}$
$\begin{aligned} & \text { LMS platform display } \\ & \text { was nice. }\end{aligned}$

15. Assignment submission and quiz completion through LMS Platform become faster, more $\begin{array}{rcrccr}4.17 & 48 & 55 & 18 & 4 & 0 \\ & (38.4 \%) & (44 \%) & (14.4 \%) & (3.2 \%) & (0 \%)\end{array}$ effective and efficient.

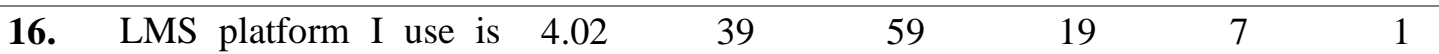




\begin{tabular}{|c|c|c|c|c|c|c|c|}
\hline & $\begin{array}{l}\text { quite stable and easily } \\
\text { accessible. }\end{array}$ & & $(31.2 \%)$ & $(47.2 \%)$ & $(15.2 \%)$ & $(5.6 \%)$ & $(0.8 \%)$ \\
\hline 17. & $\begin{array}{l}\text { Quality of teaching and } \\
\text { learning through the } \\
\text { LMS I use is as good as } \\
\text { face-to-face. }\end{array}$ & 3.28 & $\begin{array}{c}23 \\
(18.4 \%)\end{array}$ & $\begin{array}{c}31 \\
(24.8 \%)\end{array}$ & $\begin{array}{c}37 \\
(29.6 \%)\end{array}$ & $\begin{array}{c}27 \\
(21.6 \%)\end{array}$ & $\begin{array}{c}7 \\
(5.6 \%)\end{array}$ \\
\hline 18. & $\begin{array}{l}\text { In general, I am satisfied } \\
\text { learning English using } \\
\text { LMS platform. }\end{array}$ & 3.65 & $\begin{array}{c}26 \\
(20.8 \%)\end{array}$ & $\begin{array}{c}46 \\
(36.8 \%)\end{array}$ & $\begin{array}{c}38 \\
(30.4 \%)\end{array}$ & $\begin{array}{c}14 \\
(11.2 \%)\end{array}$ & $\begin{array}{c}1 \\
(0.8 \%)\end{array}$ \\
\hline 19. & $\begin{array}{l}\text { I want to keep learning } \\
\text { English with LMS } \\
\text { Platform in the future. }\end{array}$ & 3.46 & $\begin{array}{c}24 \\
(19.2 \%)\end{array}$ & $\begin{array}{r}40 \\
(32 \%)\end{array}$ & $\begin{array}{c}38 \\
(30.4 \%)\end{array}$ & $\begin{array}{c}16 \\
(12.8 \%)\end{array}$ & $\begin{array}{c}7 \\
(5.6 \%)\end{array}$ \\
\hline 20. & $\begin{array}{l}\text { I recommend other } \\
\text { students or teachers to } \\
\text { use LMS. }\end{array}$ & 3.82 & $\begin{array}{c}37 \\
(29.6 \%)\end{array}$ & $\begin{array}{c}39 \\
(31.2 \%)\end{array}$ & $\begin{array}{c}4 \\
(32 \%)\end{array}$ & $\begin{array}{c}8 \\
(6.4 \%)\end{array}$ & $\begin{array}{c}1 \\
(0.8 \%)\end{array}$ \\
\hline
\end{tabular}

From 20 statements that have been responded by 125 students, the writer can identify and categorize five main aspects that contribute students' perception of LMS such as Google Classroom, Schoology, Moodle, Edmodo, etc.. Here is the categorization or classification of the results of data:

Table 3: Recapitulations of Students' Perceptions

\begin{tabular}{|c|c|c|c|c|}
\hline \multirow{2}{*}{ Classification } & \multirow{2}{*}{ Number } & \multicolumn{3}{|c|}{ Percentage (\%) } \\
\hline & & $\mathbf{S A}+\mathbf{A}$ & $\mathbf{N}$ & $\mathbf{D}+\mathbf{S D}$ \\
\hline Features and Display & $\begin{array}{c}1,11,12,13, \\
14\end{array}$ & 69.92 & 24 & 5.92 \\
\hline System Quality & 16,17 & 60.8 & 22.4 & 16.8 \\
\hline Perceived Usefulness & $\begin{array}{l}3,4,5,6,7 \\
\quad 8,15\end{array}$ & 59.65 & 31.42 & 8.91 \\
\hline Satisfaction & $2,18,19,20$ & 59.8 & 29.6 & 10.6 \\
\hline English Competence & 9,10 & 51.2 & 37.6 & 11.2 \\
\hline Total & 20 Items & & & \\
\hline
\end{tabular}

Based on the recapitulation questionnaire above, it can be seen that Features and Display has strong response from the students', since $69.92 \%$ respondents were chosen Agree and Strongly Agree. Most of students viewed LMS has a good features to facilitate them in doing learning process. Another dominant aspect that has a solid response is system quality by $60.8 \%$ responses, Perceived Usefulness with 59.65\%, Satisfaction by 59.8\% respondents, and English Competence by $51.2 \%$ responses. The second result was Neutral 
with $24 \%, 22.4 \%, 31.42 \%, 37,6 \%$, and 29, 6\%. The last result was Disagree and Strongly Disagree with $5.9 \%, 16.8 \%, 8.91 \%, 11.2 \%$, and $10.6 \%$ which were get small number of responses.

\section{Open-Ended Questionnaire}

This open-ended questionnaire contains one question that is expected to be answered and to strengthen the results in close-ended questionnaire. Here is the following question and the number of participants:

Table 4: Open-Ended Questionnaire

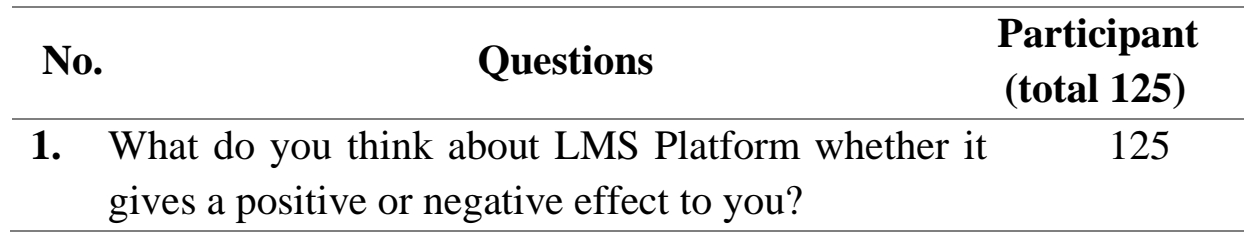

Based on the open-ended questionnaire above, it can be seen that 125 respondents answer the question by explaining the negative and positive side based on their experiences when learning English using LMS. Below are some examples of students' responses that the writer chose randomly to give the obvious data to the study.

Table 5: Sample Response of Open-Ended Questionnaire

\begin{tabular}{|c|c|}
\hline Questions & Samples of 125 Learner' response \\
\hline \multirow{5}{*}{$\begin{array}{l}\text { 1. What do you think } \\
\text { about LMS } \\
\text { Platform whether } \\
\text { it gives a positive } \\
\text { or negative effect } \\
\text { to you? }\end{array}$} & $\begin{array}{l}\text { "It really gives a positive impact. The material is } \\
\text { easier to understand, because the availability of } \\
\text { explaining video, quiz, etc." (respondent no.56) }\end{array}$ \\
\hline & $\begin{array}{l}\text { "The positive side of LMS is making more confident } \\
\text { to speak up when using a video conference, since online } \\
\text { and offline learning vibe is very different. I feel more } \\
\text { comfortable talking online. While the negative side of } \\
\text { LMS is unclearness of teacher explanation. Sometimes } \\
\text { teacher only gives text without discussion, and it's hard } \\
\text { to ask. I doubt whether or not I understand the } \\
\text { material." (learner no.58) }\end{array}$ \\
\hline & $\begin{array}{l}\text { "Positive: even though it's virtual the learning } \\
\text { process is as well as face to face learning. Thus it } \\
\text { facilitates us in learning. Negative: limited or internet } \\
\text { quota." (student no.17). }\end{array}$ \\
\hline & $\begin{array}{l}\text { I think the negative side of LMS is many students are } \\
\text { difficult to reach the internet, so they miss the } \\
\text { material." (student no. 20) }\end{array}$ \\
\hline & "Positive impact is easy to understand. \\
\hline
\end{tabular}


Negative impact is sometimes the LMS is pending/ slow to access." (student no. 23)

"Positive: more varieties don't bore, because the platform that used not only GCR but also YouTube or voice over, more relaxes.

Negative: We cannot 100\% understand the material, especially Grammar. The assignment was often cheated. We can search the answer when quiz." (student no. 32)

"It gives the positive impact, since some features written/shown in English. Thus it accidently improves my speaking and reading skill." (student no.34)

"Positive impact of LMS, perhaps, it is easier for us to learn from home and open the Platform. While the negative impact of LMS is sometimes it makes lazy, and the learning from the video is sometimes unclear" (student. 42)

"I think there is a positive and negative side. The positive side is good, because it's efficient in doing assignment (when online learning/ pandemic). The negative side is using LMS is not as clear as face to face learning and it is bad to steady use LMS" (student no. 44)

"Mostly LMS is positive, but if the teacher also doesn't give the material, the students are confused about what they want to learn. Thus the platform is not too decisive the quality of the teacher and the willingness to learn of the students will determine the outcome of the learning process during the pandemic" (student no. 50).

"Since using the LMS, teaching has become less enthusiastic, because it does not meet face-to-face with lecturers. Students are delay postponing the assignments because they are lazy to open the application" (student no. 67)

"It's quite effective, because it's easy to access. However, the internet connection is become the disadvantage." (student no. 71)

"The positive impact is LMS Platform Web-base is quite enough providing features for learning process. However the negative side is the use of quota internet and less interactive if it's done continuously." (student no. 75)

"I think the use of LMS during pandemic is quite 
helpful to facilitating English assignment, because the feature is easy to use. However there is a negative side as well. Learning English through LMS is hard to understand the material that has been given, because it is really different with the explanation given from teacher. Moreover login access and internet network is sometimes become an obstacle in using LMS." (student no. 87)

"LMS that I used in online learning give positive and negative impact. It's positive, because we know how to use technology when using LMS. Moreover technology can motivate us in learning.

The negative side is the unstable internet connection which interrupts the learning process." ( student no. 90)

The positive impact: reading material is easy to understand by share screen feature, while it's a bit hard for listening section, since it is constrained by network." (student no. 97)

"The positive impact is clearly more flexible, more effective, and free access anywhere. The negative side is less interaction, and technical error or bad signal." (student no. 102)

"LMS Platform gives a positive effect to me, because LMS facilitate me to download English material and upload assignment" (student no. 105)

"actually, LMS is facilitate in submitting the assignment, but it is wasteful of quota" (student no. 121)

"I feel more active and brave using English on LMS, because I didn't meet my friend in face-to-face. However LMS sometimes slow and take big internet quota." (Student no. 125)

According to the open-ended question above, students are answer in positive and negative side of LMS. They explained the benefit of LMS which is easy to do and submit the assignment. It shows on students' response (no. 44, 87, 105, and 125) in the table. They add this is happen because the easy feature which available in LMS. Moreover the feature is written in English which has improved their speaking and reading (no. 34). Another response shown (no. 56, 23, 17, and 35) students are easy to understand the material, since the learning process is as well as face to face learning. They add (no. 58) LMS is making more confident to speak up in virtual. LMS is flexible and efficient, since students can access anywhere and on any devices. It shows on some response $($ no. 71,102$)$ in the table. However, they also told 
(no. 17, 20, 23, 71, 80, 90, 102, 121) that slow network connection and wasteful of quota is the biggest obstacle their face, especially in listening section (no. 97).

\section{DISSCUSSION}

As we seen on the previous section above, Learning Management System has two sides from the students. Overall students gave positive feedback on Learning Management System in facilitating their English learning. They were most positive on Features and Display (69.92\%). It is because there are lots of features on LMS which facilitate the students starting from submit assignment, do quizzes, exam, and sharing any types of file. They are also easy to make a communication forum between students-teacher or even students-students.

The second aspect that gave a positive feedback is System Quality (60.8\%), most of students said LMS is easily accessible $(\mathrm{M}=4.02, \mathrm{SD}=0.87)$. System of LMS is stable and it can run everywhere to sustain their English learning. However based on the response on open-ended questionnaire, most of students said the use of LMS is wasteful of quota, and sometimes slow. This could be happen, since the LMS system is requiring an internet connection which is not always good.

The third aspects is Perceived Usefulness (59.65\%). Learning Management System (LMS) is considered capable to facilitate student English learning. They find LMS is fun and can motivate them in learning. It has been discovered that online learning directly benefits students' listening, reading, writing, and speaking abilities, as well as their learning and motivation (Ling et al., 2019). Next aspect is Satisfaction (59.85\%) which students gave positive spot on it. They got a new experience learning using LMS Platform, and tend to continue their learning process using LMS. This is supported by Komara (2020) who stated students wanted to continue using. LMS for their future English learning, and recommended it to other students, since it has benefits.

The last aspect is English Competence (51.2\%). Students think their English skill is developed, especially in speaking and reading, since mostly LMS is written in English. Another advantage is they can easily download the material, and learned it over and over again. This result shows that students can adjust their English learning course independently and improving their English. It is supported by Sánchez \& Hueros (2010) who stated using LMS can navigate students' learning material to suit their needs.

\section{CONCLUSIONS}

This study has found students' perception utilized in online English learning situation during COVID 19 pandemic. It indicates that the use of LMS affected learning process during the pandemic within the system quality, features and display, perceived usefulness, English competence, and satisfaction. Lots of benefits are received by the students. LMS facilitate their learning process, because the adequate features which available on it. It also improves students' English skill and it makes them actively learning English. Students found that LMS is fun and motivated them. They seemed really enjoy applying LMS on their English learning. By using 
Learning Management System, the learning teaching process is optimized and be effective as one as flexible learning environment for the participant is created. However the internet network becomes a boomerang for the students when they didn't get a good signal. They may miss the learning material. Even though LMS is free to be downloaded, students and parents should set their money to buy an internet quota. This could be one of the limitations in using LMS. Even though LMS is flexible, it can't run perfectly if the internet connection didn't support the LMS.

For the future research, this study can strengthen the literatures of LMS. It is strongly suggested to find differents variables or specified the brand of LMS such as Google Classroom, Moodle, Edmodo, Schoology, and etc. So, it can be checked through the experiments or correlation or impacts of LMS in ELT skills and subskills.

\section{REFERENCES}

Ahmadi, M. R. (2018). The use of technology in English Language Learning: A Literature Review. International Journal of Research in English Education (IJREE), 3(2), 115-125.

Alfa, R. R. (2020). USING PODCAST AS AUTHENTIC MATERIALS TO DEVELOP STUDENTS ' SPEAKING SKILL. 4(1), 65-74.

Bhalla, J. (2013). Computer Use by School Teachers in Teaching-learning Process. 1(2). https://doi.org/10.11114/jets.v1i2.98

Cavus, N. (2011). Investigating mobile devices and LMS integration in higher education: Student perspectives. Procedia Computer Science, 3, 1469-1474. https://doi.org/10.1016/j.procs.2011.01.033

Damnjanovic, V., Jednak, S., \& Mijatovic, I. (2015). Factors affecting the effectiveness and use of Moodle: students' perception. Interactive Learning Environments, 23(4), 496-514. https://doi.org/10.1080/10494820.2013.789062

Deli, M., \& Allo, G. (2020). Is the online learning good in the midst of Covid-19 Pandemic? The case of EFL learners. Jurnal Sinestesia, 10(1), 1-10.

Komara, C. (2020). Students 'View of Learning Management System ( LMS ) Used in Online English Learning Class during Covid-19 Pandemic Period. December 2019, 1-12.

Leavy, P. (2017). Research Design (Quantitative, Qualitative, Mixed Methods, Art-Based, and Community-Based Participatory Research Approaches).

Ling, L. H., Wen, C. H., Hazwani, N., \& Lateh, M. (2019). Non-Chinese Students 'Perception on E-Learning in Enhancing Chinese Non- Chinese Students' Perception on E -Learning in Enhancing Chinese Language Skills. International Journal of Language Education and Applied Linguistics, 9(2), 43-54.

Muthuprasad, T., Aiswarya, S., Aditya, K. S., \& Jha, G. K. (2021). Social Sciences \& Humanities Open Students' perception and preference for online education in India during COVID -19 pandemic. Social Sciences \& Humanities Open, 3(1), 100101. https://doi.org/10.1016/j.ssaho.2020.100101

Pérez-pérez, M., Serrano-bedia, A. M., García-piqueres, G., Pérez-pérez, M., \& Serrano-bedia, A. M. (2019). An analysis of factors affecting students ' perceptions of learning outcomes with Moodle An analysis of factors a ff ecting students ' perceptions of learning outcomes with Moodle. Journal of Further and Higher Education, 00(00), 1-16. https://doi.org/10.1080/0309877X.2019.1664730

Sánchez, R. A., \& Hueros, A. D. (2010). Computers in Human Behavior Motivational factors 
that influence the acceptance of Moodle using TAM. 26, 1632-1640. https://doi.org/10.1016/j.chb.2010.06.011

Shatunova, O., Anisimova, T., Sabirova, F., \& Kalimullina, O. (2019). Journal of Social Studies Education Research STEAM as an Innovative Educational Technology. Journal of Social Studies Education Research, 10(2), 131-144.

Vaske, J. J., \& Beaman, J. (2008). Rethinking Internal Consistency in Cronbach ${ }^{\text {ee }}$ alpha. Human Dimensions of Natural Resources. 